\title{
Analisis Kepuasan Konsumen terhadap Kualitas Produk dan Pelayanan di Voltvet Eatery and Coffee menggunakan Metode Customer Satisfaction Index (CSI) \\ Analysis of Customer Satisfaction on Quality Products and Services at Voltvet Eatery and Coffee using The Method of Customer Satisfaction Index (CSI) \\ Made Nanda Pranata, Amna Hartiati*, Cokorda Anom Bayu Sadyasmara \\ PS Teknologi Industri Pertanian, Fakultas Teknologi Pertanian, Universitas Udayana, Kampus Bukit Jimbaran, Badung, Kode pos : 80361; Telp/Fax : (0361) 701801.
}

Diterima 05 Agustus 2019 / Disetujui 28 Agustus 2019

\begin{abstract}
The purpose of this research is to: (1) find out the attribute of products and services that are considered important by customers to achieve customer satisfaction of the quality products and service. (2) determine the level of customer satisfaction with the quality of products and services. (3) Determine attributes that need to get a priority in quality improvement of products and services to enhance customers satisfaction at Voltvet Eatery and Coffee. This research uses the methods of Customer Satisfaction Index (CSI) and the Potential Gains In Customer Values (PGCV) that includes quality products including food, beverage, coffee, price and promotion, while the quality of service including physical evidence, reliability, responsiveness, assurance, and empathy, respondents used amounted to 94. The data obtained were analyzed using SPSS 25.0 applications and microsoft excel. The Result of the research showed that all of the product and service quality attribute are considered important by customers. The level of customer satisfaction based on the CSI to quality product is $82,85 \%$ and on services $83,83 \%$, which shows that customers very satisfied with product and service at Voltvet Eatery and Coffee. Quality attribute product that needs attention is the presentation with a PGCV index value 4.017; discount with the value of the index PGCV 3.891; and the consistency of food per serving with the value of the index PGCV 3.838; while services quality attribute that need to gain priority are availability of parking lots with the value of the index PGCV 4.200; wifi facilities with the value of the index PGCV 3.636, and employee appearance with indeks of PGCV 3.121.
\end{abstract}

Keywords: product quality, service quality, Customer Satisfaction Index (CSI), Potential Gain In Customer Values (PGCV).

*Korespondensi Penulis:

Email : amnahartiati@unud.ac.id 


\section{PENDAHULUAN}

Dewasa ini seiring dengan berkembangnya zaman, gaya hidup (life style) masyarakat juga mengalami perkembangan. Masyarakat lebih cenderung memilih meluangkan waktunya untuk sekedar bersantai dan berkumpul bersama teman di tempat yang dapat memberikan kenyamanan dalam beraktivitas, khususnya kalangan muda lebih memilih meluangkan waktunya untuk bersantai di tempat yang menurut mereka dapat memberikan kenyamanan dan fasilitas yang mereka butuhkan. Salah satu tempat yang sering menjadi tujuan tersebut adalah kedai kopi. Menurut Yahya (2009), pada era persaingan bisnis yang semakin ketat di bidang kedai kopi, maka kedai kopi harus bisa mempertahankan usaha berserta pelanggannya. Usaha yang dapat dilakukan kedai kopi adalah dengan meningkatkan kualitas menu, membuat inovasi menu baru, dan juga dengan meningkatkan kualitas pelayanan pada karyawan untuk senantiasa memberi kepuasan kepada pelanggannya. Dari sekian banyak kedai kopi unik dan menarik di Denpasar, Voltvet Eatery and Coffee adalah salah satu kedai kopi yang juga menawarkan hidangan lain seperti main course dan pastry.

Voltvet Eatery and Coffee didirikan pada tahun 2015. Konsep Voltvet Eatery and Coffee adalah kedai kopi dengan nuansa antik (vintage) yang ditunjukkan melalui interiornya yang mencirikan rumah klasik pada zaman dahulu. Arti dari nama Voltvet itu sendiri adalah voltage veteran yaitu menghidupkan suasana jalan veteran melalui energi veteran itu sendiri. Omzet tertinggi yang dihasilkan oleh Voltvet Eatery and Coffee yaitu sebesar 90 juta/bulan. Omzet ini dapat dihasilkan oleh Voltvet Eatery and Coffee pada akhir tahun namun pada pertengahan tahun omzet dari Voltvet Eatery and Coffee mengalami penurunan. Hal ini disebabkan oleh menurunnya omzet dan jumlah konsumen yang datang mengunjungi Volvet Eatery and Coffee yaitu sebesar 21\% dari periode akhir tahun 2017 ke pertengahan tahun berikutnya pada tahun 2018 .

Berkaitan dengan uraian diatas, maka dilakukan kajian mengenai pengaruh kualitas produk dan pelayanan karyawan terhadap kepuasan konsumen menggunakan metode Customer Satisfaction Index (CSI). Metode ini telah digunakan pada penelitian Utama (2017) terkait analisis sikap dan kepuasan konsumen terhadap 2 merek kopi instan dan mendapatkan hasil dengan tingkat kepuasan masing-masing lebih dari $70 \%$, juga Ari (2018) tentang analisis tingkat kepuasan pelanggan, pengaruh kondisi coffee shop, kualitas produk, dan kualitas layanan terhadap kepuasan pelanggan di Kopi Made. Hasil penelitian tersebut dapat menunjukkan bahwa indeks kepuasan pelanggan Kopi Made dalam kategori sangat puas dengan nilai lebih dari $80 \%$.

Customer Satisfaction Index (CSI) adalah sebuah metode yang digunakan untuk mengetahui tingkat kepuasan konsumen secara menyeluruh dengan melihat tingkat kepuasan dari atribut-atribut produk dan jasa (Aritonang, 2005). Kelebihan dari metode CSI adalah efisien (tidak hanya indeks kepuasaan tetapi sekaligus memperoleh informasi terkait dengan atribut yang diinginkan) Metode CSI juga memiliki kekurangan yaitu tidak dapat menentukan atribut prioritas dari artribut-atribut yang dihasilkan. Diperlukan suatu metode pendukung ialah Potential Gain in Customer Values (PGCV). Potential Gain in Customer Values (PGCV) adalah alat yang digunakan untuk mengetahui skala prioritas atributatribut yang harus diperhatikan dan ditingkatkan oleh perusahaan (Muheir, 2015).

Tujuan penelitian ini adalah (1) mengetahui atribut produk dan pelayanan yang dianggap penting oleh konsumen untuk 
tercapainya kepuasan terhadap kualitas produk dan pelayanan, (2) menentukan tingkat kepuasan konsumen terhadap kualitas produk dan pelayanan, (3) menentukan atribut yang perlu menjadi prioritas dalam perbaikan kualitas produk dan pelayanan untuk meningkatkan kepuasan konsumen di Voltvet Eatery and Coffee.

\section{METODE PENELITIAN}

Penelitian dilakukan di Voltvet Eatery and Coffee, J1. Veteran no.11a, Dauh Puri Kaja, Denpasar, dan di laboratorium sistem manajemen industri pada bulan Maret-Mei 2019. Penelitian menggunakan kuesioner dan dianalisis menggunakan SPSS 25. Kuesioner ditujukan kepada konsumen Voltvet Eatery and Coffee. Jumlah responden yang digunakan dalam penelitian ini sebanyak 94 orang berdasarkan metode Slovin. Tahap pertama yang dilakukan dalam penelitian ini adalah survei pendahuluan. Survei dilakukan dengan cara melakukan observasi ke Voltvet Eatery and Coffee. Tahap berikutnya adalah mengidentifikasi variabel-variabel atribut penelitian dengan cara studi pustaka dan hasil wawancara dengan pihak manajemen kedai kopi. Perumusan kuesioner dilakukan setelah menetapkan variabel - variabel penelitan yang akan digunakan. Sebelum kuesioner disebar, kuesioner harus diuji validitas dan reliabilitas terlebih dahulu untuk mengetahui sejauh mana alat ukur dapat mengukur apa yang akan diukur. Apabila kuesioner sudah dinyatakan valid dan reliabel maka dilanjutkan ke tahap penentuan populasi dan sampel. Setelah data diperoleh maka dilakukan analisis data untuk menentukkan atribut-atribut yang penting, tingkat kinerja masing-masing atribut baik produk dan pelayanan, tingkat kepuasan konsumen dan menentukan atribut yang perlu mendapat prioritas untuk perbaikkan.

Analisa kepuasan konsumen diukur melalui atribut-atribut kualitas produk dan pelayanan yang terdapat dalam: derajat kepentingan dan kepuasan. Pengukuran derajat kepentingan, harapan dan pelayanan yang dirasakan oleh konsumen Voltvet Eatery and Coffee dilakukan dengan skala Likert. Pengukuran tingkat kepuasan konsumen digunakan Customer Satisfaction Index (CSI) dan Potential Gain in Customer Values (PGCV). Untuk menghitung CSI maka dapat dilakukan langkah-langkah sebagai berikut: menentukan Mean Importance Score (MIS), Weight Factors (WF), Weight Score (WS), dan yang terakhir menentukan Customer Satisfaction Index (CSI). Nilai CSI dalam penelitian ini dibagi dalam lima kriteria dari tidak puas sampai dengan sangat puas.

Potential Gain in Customer Values (PGCV) adalah alat yang digunakan untuk mengetahui skala prioritas atribut-atribut yang harus diperhatikan dan ditingkatkan oleh perusahaan (Muheir, 2015). Analisis dari Customer Satisfaction Index kurang dapat merekomendasikan perbaikan yang menjadi prioritas utama. Diperlukan suatu metode pendukung yaitu analisis melalui angka indeks PGCV. Langkah-langkah untuk mengetahui indeks PGCV adalah: Achive Customer Value (ACV), Ultimately Desire Customer Value (UDCV), Indeks Potential Gain in Customer Value (PGCV).

\section{HASIL DAN PEMBAHASAN}

\section{Karakteristik Responden}

Pada penelitian ini karakteristik responden dibutuhkan untuk mengetahui keterkaitan antara konsumen dengan atributatribut produk dan pelayanan di Voltvet Eatery and Coffee. Kuesioner ditujukan kepada konsumen Voltvet Eatery and Coffee. Jumlah responden yang digunakan dalam penelitian ini sebanyak 94 orang. Karakteristik responden dalam penelitian ini ditunjukkan dari jenis kelamin, pekerjaan, usia, dan pendapatan. 


\section{Karakteristik Responden Berdasarkan Jenis Kelamin}

Widiana (2013) menyatakan perbedaan jenis kelamin mempunyai pengaruh terhadap pembelian produk atau jasa. Hal ini disebabkan oleh perbedaan kebutuhan dan sifat alamiah pada setiap orang. Karakteristik responden berdasarkan jenis kelamin, dibagi 2 kategori. Kedua kategori tersebut dapat dilihat pada Tabel 1.

Tabel 1. Karakteristik responden Voltvet Eatery and Coffee berdasarkan jenis kelamin.

\begin{tabular}{lcr}
\hline Karakteristik Responden & Jumlah (Orang) & Presentase (\%) \\
\hline Laki-laki & 54 & 57,45 \\
Perempuan & 40 & 42,55 \\
\hline \multicolumn{1}{c}{ Total } & 94 & 100,00 \\
\hline
\end{tabular}

Pada Tabel. 1 dapat dinyatakan bahwa responden pengunjung Voltvet Eatery and Coffee yaitu laki-laki lebih banyak daripada responden perempuan yaitu sebanyak 54 orang $(57,45 \%)$ sedangkan perempuan sebanyak 40 orang (42,55\%). Lebih banyaknya konsumen laki-laki yang membeli kopi di Voltvet Eatery and Coffee sesuai dengan penelitian dari Chairawani (2015) bahwa minum kopi biasanya didominasi oleh pria.

\section{Karakteristik Responden Berdasarkan Pekerjaan}

Para pengunjung di Voltvet Eatery and Coffee terdiri dari konsumen yang memiliki berbagai macam pekerjaan. Karakteristik Voltvet Eatery and Coffee berdasarkan jenis pekerjaan dapat dilihat pada Tabel 2.

Tabel 2. Karakteristik responden Voltvet Eatery and Coffee berdasarkan jenis pekerjaan.

\begin{tabular}{|c|c|c|}
\hline Jenis Pekerjaan & Jumlah (Orang) & Presentase $(\%)$ \\
\hline Pelajar & 9 & 9,57 \\
\hline Mahasiswa & 40 & 42,55 \\
\hline Pegawai Negeri & 14 & 14,89 \\
\hline Pegawai Swasta & 8 & 8,51 \\
\hline Wiraswasta & 11 & 11,70 \\
\hline Lain-lain & 12 & 12,80 \\
\hline Total & 94 & 100,00 \\
\hline
\end{tabular}

Berdasarkan hasil dari Tabel 2 dapat dinyatakan bahwa responden yang terbanyak adalah kalangan mahasiswa sebanyak $42,55 \%$. Beberapa perguruan tinggi yang ada di sekitar Voltvet Eatery and Coffee seperti Universitas Dwijendra, Universitas Udayana, dan Universitas Mahasaraswati, beragam pilihan menu yang disediakan, dan tempat yang strategis di dekat pusat kota Denpasar, menjadi dasar bahwa mahasiswa paling mendominasi untuk berkumpul di Voltvet Eatery and Coffee.
Karakteristik Responden Berdasarkan Usia Bertambahnya usia berhubungan dengan pengalaman seseorang dalam memilih produk barang atau jasa (Widiana, 2013). Pada Tabel 3 terlihat bahwa sebagian besar responden yang menikmati produk Voltvet Eatery and Coffee berusia 17-25 tahun yaitu sebesar 53,20\%. Karakteristik responden Voltvet Eatery and Coffee berdasarkan usia dapat dilihat pada Tabel 3. Poin karakteristik berdasarkan usia yang didominasi oleh usia 17-25 tahun sejalan atau 
berbanding lurus dengan poin karakteristik berdasarkan pekerjaan, bahwa mahasiswa/pelajar biasanya berusia 17-25 tahun.

Tabel 3. Karakteristik responden Voltvet Eatery and Coffee berdasarkan usia.

\begin{tabular}{ccr}
\hline Usia (tahun) & Jumlah (orang) & Presentase (\%) \\
\hline $17-25$ & 50 & 53,20 \\
$26-35$ & 25 & 26,60 \\
$36-45$ & 13 & 13,83 \\
$45-50$ & 6 & 6,40 \\
\hline Total & 94 & 100,00 \\
\hline
\end{tabular}

\section{Karakteristik Responden Berdasarkan Pendapatan}

Pendapatan merupakan variabel sosial ekonomi lain yang sering digunakan untuk memperkirakan kedudukan kelas sosial, semakin besar pendapatan seseorang akan sangat mudah memutuskan untuk membeli suatu barang atau jasa (Widiana, 2013). Berdasarkan hasil data responden diketahui sebagian besar responden memiliki rata-rata pendapatan per bulan sebesar $<\mathrm{Rp}$ 1.500 .000 yaitu sebesar $37,23 \%$. Sedangkan responden yang paling terkecil yaitu sebesar
5,32\% memiliki pendapatan perbulan $>\mathrm{Rp}$ 5.000.000. Dari hasil data tersebut responden yang memiliki rata-rata pendapatan per bulan sebesar <Rp 1.500.000 adalah mahasiswa. Mahasiswa termasuk pada kelompok yang bersekolah dan penerima pendapatan sehingga mahasiswa tidak memiliki pendapatan permanen sendiri. Pendapatan mahasiswa biasanya berasal dari uang saku dari orang tua (Ridony, 2014). Karakteristik responden Voltvet Eatery and Coffee berdasarkan pendapatan per bulan dapat dilihat pada Tabel 4.

Tabel 4. Karakteristik responden Voltvet Eatery and Coffee berdasarkan pendapatan.

\begin{tabular}{ccr}
\hline Tingkat Penghasilan & Jumlah (Orang) & Presentase (\%) \\
\hline$<1.500 .000$ & 35 & 37,23 \\
$1.500 .000-2.500 .000$ & 31 & 32,97 \\
$2.500 .000-3.500 .000$ & 14 & 14,89 \\
$3.500 .000-5.000 .000$ & 9 & 9,60 \\
$>5.000 .000$ & 5 & 5,32 \\
\hline Total & 94 & 100,00 \\
\hline
\end{tabular}

\section{Penentuan Kepuasan Konsumen}

Penentuan kepuasan konsumen menggunakan metode Customer Satisfaction Index (CSI) atribut pada kuesioner kepentingan produk yang mendapatkan skor terkecil adalah atribut penyajian/platting minuman yang menarik (atribut no. 7) dengan skor rata- rata sebesar 4,03. Atribut dengan skor terbesar adalah cita rasa kopi (atribut no. 10) dengan skor rata-rata sebesar 4,30 . Berdasarkan hal tersebut, maka dari 20 (dua puluh) atribut kualitas produk pada penelitian ini, seluruhnya dianggap penting oleh konsumen karena memiliki rata-rata nilai Mean Importance Score (MIS) lebih besar dari 4 (empat). Sulistyowati (2002) menyatakan bahwa pengolahan kopi yang kurang baik pada saat proses fermentasi menimbulkan kerusakan citarasa seperti munculnya rasa asam yang berlebihan dan bau busuk. Pada saat pengolahan kopi proses yang terpenting yaitu pada saat penyangraian. 
Proses penyangraian akan menentukan citarasa kopi yang dihasilkan. Perhitungan pada setiap tahapan metode CSI kemudian diperoleh indeks kepuasan untuk kualitas produk Voltvet Eatery and Coffee sebesar $82,85 \%$. Hal ini mengindikasikan bahwa konsumen Voltvet Eatery and Coffee sudah sangat puas dengan produk yang ditawarkan. Nilai Mean Importance Score (MIS), Mean Satisfaction Score (MSS), Weight Factors (WF), Weight Score (WS) setiap atribut kualitas produk dapat dilihat pada Tabel 5.

Atribut pada kuesioner kepentingan pelayanan yang mendapatkan skor terkecil adalah atribut ketersediaan lahan parkir (atribut no. 1) dengan skor rata-rata 4,05 dan untuk atribut dengan skor terbesar adalah kesungguhan dalam melayani pelanggan (atribut no.13) dengan skor rata-rata 4,56. Berdasarkan hal tersebut, maka dari 14 (empat belas) atribut kualitas pelayanan pada penelitian ini, seluruhnya dianggap penting oleh konsumen karena memiliki rata-rata nilai MIS lebih besar dari 4 (empat). Keberhasilan di dalam melayani tidak hanya sekedar tertumpu pada kemauan saja, tetapi juga harus pula didasarkan pada power (kekuatan), ability (kemampuan), morality (moral), integrity (integritas), dan total accountability (tanggungjawab total) (Atep, 2004). Perhitungan pada setiap tahapan metode CSI kemudian diperoleh indeks kepuasan untuk kualitas pelayanan Voltvet Eatery and Coffee sebesar 83,83\%. Hal ini mengindikasikan bahwa konsumen Voltvet Eatery and Coffee sudah sangat puas dengan pelayanan yang diberikan. Nilai Mean Importance Score (MIS), Mean Satisfaction Score (MSS), Weight Factors (WF), Weight Score (WS) setiap atribut kualitas pelayanan dapat dilihat pada Tabel 6.

Tabel 5. Indeks kepuasan konsumen berdasarkan atribut kualitas produk Voltvet Eatery and Coffee.

\begin{tabular}{clrrrc}
\hline No & \multicolumn{1}{c}{ Atribut } & MIS & MSS & WF & WS \\
\hline 1 & Variasi menu makanan & 4,09 & 4,18 & 4,94 & 0,206 \\
2 & Rasa makanan & 4,18 & 4,07 & 5,05 & 0,206 \\
3 & Penyajian/Platting makanan yang menarik & 4,22 & 4,20 & 5,10 & 0,214 \\
4 & Konsistensi makanan setiap penyajian & 4,05 & 4,05 & 4,90 & 0,199 \\
5 & Variasi menu minuman & 4,20 & 4,11 & 5,08 & 0,209 \\
6 & Rasa minuman & 4,23 & 4,16 & 5,12 & 0,213 \\
7 & Penyajian/Platting minuman yang menarik & 4,03 & 4,15 & 4,87 & 0,202 \\
8 & Konsistensi minuman setiap penyajian & 4,06 & 4,03 & 4,91 & 0,198 \\
9 & Variasi menu kopi & 4,07 & 4,09 & 4,92 & 0,201 \\
10 & Cita rasa kopi & 4,30 & 4,04 & 5,19 & 0,210 \\
11 & Penyajian yang menarik & 4,11 & 4,19 & 4,96 & 0,208 \\
12 & Aroma kopi & 4,10 & 4,12 & 4,95 & 0,204 \\
13 & Kesesuaian harga makanan dengan porsi & 4,14 & 4,13 & 5,00 & 0,206 \\
14 & Kesesuaian harga minuman dengan porsi & 4,17 & 4,10 & 5,04 & 0,206 \\
15 & Kesesuian harga kopi dengan porsi & 4,16 & 4,23 & 5,03 & 0,213 \\
16 & Kesesuian kualitas makanan dengan harga & 4,19 & 4,31 & 5,07 & 0,218 \\
17 & Kesesuian kualitas minuman dengan harga & 4,15 & 4,14 & 5,01 & 0,208 \\
18 & Kesesuian kualitas kopi dengan harga & 4,13 & 4,22 & 4,99 & 0,211 \\
19 & Penggunaan Social Media & 4,12 & 4,27 & 4,98 & 0,212 \\
20 & Potongan harga & 4,04 & 4,06 & 4,89 & 0,199 \\
\hline \multicolumn{2}{r}{ Total CSI =4,142/5 (100\%) $=82,85 \%$} & & & \\
\hline & & 82,74 & 82,85 & 100,00 & 4,142 \\
\hline
\end{tabular}


Tabel 6. Indeks kepuasan konsumen berdasarkan atribut kualitas pelayanan Voltvet Eatery and Coffee.

\begin{tabular}{clrrrr}
\hline \multirow{2}{*}{ No } & \multicolumn{1}{c}{ Atribut } & MIS & MSS & WF & WS \\
\hline 1 & Ketersediaan lahan parkir & 4,05 & 4,44 & 6,58 & 0,292 \\
2 & Desain interior & 4,54 & 4,06 & 7,37 & 0,300 \\
3 & Kebersihan tempat & 4,53 & 4,18 & 7,36 & 0,308 \\
4 & Kebersihan toilet & 4,49 & 4,03 & 7,29 & 0,294 \\
5 & Penampilan karyawan & 4,23 & 4,07 & 6,87 & 0,280 \\
6 & Fasilitas wifi & 4,10 & 4,02 & 6,65 & 0,267 \\
7 & Kecepatan penyajian pesanan & 4,31 & 4,39 & 6,99 & 0,307 \\
8 & Ketepatan waktu penyajian & 4,50 & 4,21 & 7,30 & 0,308 \\
9 & Kecepatan dalam melayani konsumen & 4,41 & 4,33 & 7,17 & 0,310 \\
10 & Perilaku karyawan dalam melayani pelanggan & 4,41 & 4,30 & 7,17 & 0,308 \\
11 & Pengetahuan karyawan terhadap menu ataupun & 4,38 & 4,28 & 7,11 & 0,304 \\
& produk yang ditawarkan & & & & \\
12 & Kenyamanan pelanggan pada saat berada di & 4,52 & 4,26 & 7,34 & 0,312 \\
& Kafe & & & & \\
13 & Kesungguhan dalam melayani pelanggan & 4,56 & 4,05 & 7,41 & 0,300 \\
14 & Pelayanan yang sama tanpa memandang status & 4,55 & 4,07 & 7,39 & 0,301 \\
& Sosial & & & & \\
\hline & \multicolumn{1}{c}{ Total } & 61,61 & 58,70 & 100,00 & 4,191 \\
\hline
\end{tabular}

\section{Penentuan Prioritas Atribut Yang Harus Ditingkatkan}

Penentuan prioritas atribut yang harus ditentukan menggunakan metode Potential Gain in Customer Values (PGCV) meliputi kualitas produk dan pelayanan.

\section{Kualitas Produk}

Indeks Potential Gain Customer Value kualitas produk disajikan pada Tabel 7 . Berdasarkan Tabel 7 urutan proritas perbaikan kinerja kualitas produk adalah sebagai berikut: (1) penyajian/platting minuman yang menarik dengan nilai indeks PGCV 4,017; (2) potongan harga dengan nilai indeks PGCV 3,891; dan (3) konsistensi makanan setiap penyajian dengan nilai indeks PGCV 3,838. Banyaknya variasi makanan dan minum serta rasa yang enak bagi konsumen kurang lengkap dan sempurna apabila cara penyajian dari makanan dan minuman tersebut kurang menarik bagi konsumen. Walt (2014) menyatakan bahwa penyajian makanan/minuman juga merupakan hal yang penting karena akan memuaskan pelanggan berdasarkan pendekatan estetika. Promosi penjualan seperti potongan harga diharapkan agar konsumen dapat melakukan pembelian selanjutnya dan berkelanjutan menjadi konsumen yang loyal (Ratu, 2013). Tjiptono (2011) menyatakan kualitas yang unggul dan konsisten dapat menumbuhkan kepuasan pelanggan, dan akan memberi berbagai manfaat seperti: memberikan dasar yang baik bagi pembelian ulang, dapat mendorong terciptanya loyalitas pelanggan, dan reputasi perusahaan menjadi baik dimata pelanggan.

\section{Kualitas Pelayanan}

Indeks Potential Gain Customer Value Kualitas Pelayanan disajikan pada Tabel 8. Berdasarkan Tabel 8 urutan proritas perbaikan kinerja kualitas pelayanan adalah 
sebagai berikut: (1) ketersediaan lahan parkir dengan nilai indeks PGCV 4,200; (2) fasilitas wifi dengan nilai PGCV 3,636; dan (3) penampilan karyawan dengan nilai indeks PGCV 3,121; ketersediaan lahan parkir menjadi poin pertama yang harus menjadi perhatian pihak Voltvet Eatery and Coffee untuk ditingkatkan. Sulistyawati (2010) menyatakan bahwa tersedianya sarana parkir yang memadai dan aman merupakan faktor yang mempengaruhi konsumen dalam pembelian suatu produk, karena hal ini dapat memberikan keamanan dan kenyamanan. Poin kedua yang harus diperbaiki adalah fasilitas wifi karena koneksi/jaringan wifi di voltvet sering tidak stabil selain itu password wifi tidak ditampilkan di tempat yang strategis sehingga konsumen harus menanyakan kepada karyawan. Pada penelitian Jessica (2013) juga diperoleh bahwa fasilitas wifi merupakan variabel yang dianggap penting oleh konsumen. Nampaknya dapat dilihat bahwa kehidupan manusia kini tidak bisa terlepas dari yang namanya internet. Poin ketiga yang harus diperhatikan yaitu penampilan karyawan. Standar penampilan yang diperlukan seorang pramusaji antara lain adalah tidak boleh memelihara kumis atau jenggot, kebersihan diri dan pakaian seragam harus bersih, rapi dan diseterika (Bagyono, 2017). Hal lain yang dapat disimpulkan berdasarkan Tabel 8 adalah bahwa aspek tangible perlu diperhatikan seperti aspek atribut lainnya yang sudah baik seperti empathy dan assurance.

Tabel 7. Perhitungan indeks potential gain customer value kualitas produk

\begin{tabular}{|c|c|c|c|c|c|c|c|c|}
\hline No & Atribut & $\mathrm{P}$ & I & $\mathrm{ACV}$ & Ps & UDCV & PGCV & Prioritas \\
\hline 1 & $\begin{array}{l}\text { Penyajian/Platting } \\
\text { minuman yang menarik }\end{array}$ & 4,032 & 4,149 & 16,728 & 5 & 20,745 & 4,017 & 1 \\
\hline 2 & Potongan harga & 4,043 & 4,064 & 16,428 & 5 & 20,319 & 3,891 & 2 \\
\hline 3 & $\begin{array}{l}\text { Konsistensi makanan } \\
\text { setiap penyajian }\end{array}$ & 4,053 & 4,053 & 16,428 & 5 & 20,266 & 3,838 & 3 \\
\hline 4 & Variasi menu makanan & 4,085 & 4,181 & 17,079 & 5 & 20,904 & 3,825 & 4 \\
\hline 5 & Variasi menu kopi & 4,074 & 4,085 & 16,645 & 5 & 20,426 & 3,781 & 5 \\
\hline 6 & $\begin{array}{l}\text { Konsistensi minuman } \\
\text { setiap penyajian }\end{array}$ & 4,064 & 4,032 & 16,385 & 5 & 20,160 & 3,775 & 6 \\
\hline 7 & $\begin{array}{l}\text { Penggunaan Social } \\
\text { Media }\end{array}$ & 4,117 & 4,266 & 17,563 & 5 & 21,330 & 3,767 & 7 \\
\hline 8 & Penyajian yang menarik & 4,106 & 4,191 & 17,212 & 5 & 20,957 & 3,746 & 8 \\
\hline 9 & Aroma kopi & 4,096 & 4,117 & 16,862 & 5 & 20,585 & 3,723 & 9 \\
\hline 10 & $\begin{array}{l}\text { Kesesuian kualitas kopi } \\
\text { dengan harga }\end{array}$ & 4,128 & 4,223 & 17,433 & 5 & 21,117 & 3,684 & 10 \\
\hline 11 & $\begin{array}{l}\text { Kesesuian harga kopi } \\
\text { dengan porsi }\end{array}$ & 4,160 & 4,234 & 17,612 & 5 & 21,170 & 3,558 & 11 \\
\hline 12 & $\begin{array}{l}\text { Kesesuaian harga } \\
\text { makanan dengan porsi }\end{array}$ & 4,138 & 4,128 & 17,081 & 5 & 20,638 & 3,557 & 12 \\
\hline 13 & $\begin{array}{l}\text { Kesesuian kualitas } \\
\text { minuman dengan harga }\end{array}$ & 4,149 & 4,138 & 17,170 & 5 & 20,691 & 3,522 & 13 \\
\hline 14 & $\begin{array}{l}\text { Kesesuian kualitas } \\
\text { makanan dengan harga }\end{array}$ & 4,191 & 4,309 & 18,059 & 5 & 21,543 & 3,483 & 14 \\
\hline 15 & $\begin{array}{l}\text { Kesesuaian harga } \\
\text { minuman dengan porsi }\end{array}$ & 4,170 & 4,096 & 17,080 & 5 & 20,479 & 3,399 & 15 \\
\hline 16 & Rasa makanan & 4,181 & 4,074 & 17,035 & 5 & 20,372 & 3,338 & 16 \\
\hline 17 & $\begin{array}{l}\text { Kesesuian harga kopi } \\
\text { dengan porsi }\end{array}$ & 4,160 & 4,234 & 17,612 & 5 & 21,170 & 3,558 & 17 \\
\hline
\end{tabular}




\begin{tabular}{|c|c|c|c|c|c|c|c|c|}
\hline 18 & $\begin{array}{l}\text { Penyajian/Platting } \\
\text { makanan yang menarik }\end{array}$ & 4,223 & 4,202 & 17,747 & 5 & 21,011 & 3,263 & 18 \\
\hline 19 & Rasa minuman & 4,234 & 4,160 & 17,612 & 5 & 20,798 & 3,186 & 19 \\
\hline 20 & Cita rasa kopi & 4,298 & 4,043 & 17,374 & 5 & 20,213 & 2,838 & 20 \\
\hline
\end{tabular}

Tabel 8. Perhitungan indeks potential gain customer value kualitas pelayanan

\begin{tabular}{|c|c|c|c|c|c|c|c|c|}
\hline No & Atribut & $\mathrm{P}$ & I & $\mathrm{ACV}$ & Ps & UDCV & PGCV & Prioritas \\
\hline 1 & Ketersediaan lahan parkir & 4,053 & 4,436 & 17,981 & 5 & 22,181 & 4,200 & 1 \\
\hline 2 & Fasilitas wifi & 4,096 & 4,021 & 16,470 & 5 & 20,106 & 3,636 & 2 \\
\hline 3 & Penampilan karyawan & 4,234 & 4,074 & 17,251 & 5 & 20,372 & 3,121 & 3 \\
\hline 4 & $\begin{array}{l}\text { Kecepatan penyajian } \\
\text { Pesanan }\end{array}$ & 4,309 & 4,394 & 18,930 & 5 & 21,968 & 3,038 & 4 \\
\hline 5 & $\begin{array}{l}\text { Pengetahuan karyawan } \\
\text { terhadap menu ataupun produk } \\
\text { yang ditawarkan }\end{array}$ & 4,383 & 4,277 & 18,744 & 5 & 21,383 & 2,639 & 5 \\
\hline 6 & $\begin{array}{l}\text { Kecepatan dalam melayani } \\
\text { konsumen }\end{array}$ & 4,415 & 4,330 & 19,116 & 5 & 21,649 & 2,533 & 6 \\
\hline 7 & $\begin{array}{l}\text { Perilaku karyawan dalam } \\
\text { melayani pelanggan }\end{array}$ & 4,415 & 4,298 & 18,975 & 5 & 21,489 & 2,515 & 7 \\
\hline 8 & Ketepatan waktu penyajian & 4,500 & 4,213 & 18,957 & 5 & 21,064 & 2,106 & 8 \\
\hline 9 & Kebersihan toilet & 4,489 & 4,032 & 18,101 & 5 & 20,160 & 2,059 & 9 \\
\hline 10 & $\begin{array}{l}\text { Kenyamanan pelanggan } \\
\text { pada saat berada di kafe }\end{array}$ & 4,521 & 4,255 & 19,239 & 5 & 21,277 & 2,037 & 10 \\
\hline 11 & Kebersihan tempat & 4,532 & 4,181 & 18,947 & 5 & 20,904 & 1,957 & 11 \\
\hline 12 & $\begin{array}{l}\text { Pelayanan yang sama tanpa } \\
\text { memandang status sosial }\end{array}$ & 4,553 & 4,074 & 18,552 & 5 & 20,372 & 1,821 & 12 \\
\hline 13 & Desain interior & 4,543 & 4,064 & 18,460 & 5 & 20,319 & 1,859 & 13 \\
\hline 14 & $\begin{array}{l}\text { Kesungguhan dalam } \\
\text { melayani pelanggan }\end{array}$ & 4,564 & 4,053 & 18,498 & 5 & 20,266 & 1,768 & 14 \\
\hline
\end{tabular}

\section{KESIMPULAN DAN SARAN}

\section{Kesimpulan}

Berdasarkan penelitian yang telah dilakukan, maka dapat diambil beberapa kesimpulan sebagai berikut:

1. Seluruh atribut kualitas produk dan pelayanan dianggap penting oleh konsumen Voltvet Eatery and Coffee.

2. Tingkat kepuasan konsumen berdasarkan perhitungan CSI untuk kualitas produk adalah sebesar $82,85 \%$ dan kualitas pelayanan adalah sebesar $83,83 \%$ yang menunjukkan bahwa konsumen sangat puas dengan produk maupun pelayanan di Voltvet Eatery and Coffee.

3. Atribut-atribut kualitas pelayanan yang perlu mendapatkan prioritas utama perbaikan berdasarkan PGVC adalah ketersediaan lahan parkir, fasilitas (wifi), dan penampilan karyawan sedangkan atribut-atribut kualitas produk yang perlu mendapatkan prioritas berdasarkan PGVC adalah penyajian/platting minuman yang menarik, potongan harga, dan konsistensi makanan setiap penyajian.

\section{Saran}

Saran dari penelitian ini adalah pihak Voltvet Eatery and Coffee perlu melakukan perbaikan terhadap atribut kualitas produk dan atribut kualitas pelayanan yang mendapatkan prioritas agar tercapainya kepuasan konsumen.

\section{DAFTAR PUSTAKA}


Ari N, N. Gede dan G. Ayu. 2018. VariabelVariabel Yang Mempengaruhi Kepuasan dan Keputusan Pembelian Ulang Pada Kopi Made. Jurnal Manajemen Agribisnis. 6(2): 31-41.

Atep, A. 2004. Dasar-Dasar Pelayanan Prima: Persiapan membangun budaya pelayanan prima untuk meningkatkan kepuasan dan loyalitas pelanggan. PT Elex Media Komputindo. Jakarta.

Aritonang, R. 2005. Kepuasan Pelanggan. PT Gramedia Pustaka Utama. Jakarta.

Bagyono. 2007. Pariwisata dan Perhotelan. Alfabeta. Bandung.

Chairawani, R, I. Iskandarini dan E. Emalisa. 2015. Analisis kepuasan konsumen terhadap kedai kopi ulee kareng di kota medan. Jurnal Agrobisnis. 9(10): 1-18

Jessica, L dan Y. Sondang. 2013. Analisa Pengaruh Kualitas Layanan Terhadap kepuasan Pelanggan Di The Light Cup Cafe Surabaya Town Square Dan The Square Surabaya. Jurnal Manajemen Pemasaran. 1(1): 1-7.

Muheir, I. 2015. Analisis Tingkat Kepuasan Pelanggan dan Kualitas Pelayanan Terhadap Pelayanan Jasa Rumah Makan Menggunakan Metode Fuzzy Servqual dan Index Potential Gain Customer Value (PGCV) di Rumah Makan Ayam Goreng Suharti. Skripsi. Tidak dipublikasikan. Fakultas Sains dan Teknologi. Universitas Islam Negeri Sunan Kalijaga. Yogyakarta.

Ratu, M. 2013. Strategi Promosi Restoran Takigawa Botani Square Kota Bogor. Skripsi. Tidak dipublikasikan. Fakultas Ekonomi dan Manajemen. Institut Pertanian Bogor. Bogor.

Ridony, T. 2014. Pengeluaran Konsumsi Mahasiswa Program Studi Pendidikan Ekonomi Fakultas Ekonomi Universitas Yogyakarta. Skripsi. Tidak dipublikasikan. Fakultas Ekonomi. Universitas Negeri Yogyakarta. Yogyakarta.

Sulistyawati E, T Multifiah dan Thoyib, A. 2010. Analisis Perilaku Keputusan Konsumen dalam Pembelian Produk Patung Kayu pada Toko Kerajinan (artshop) Kecamatan Sukawati, Gianyar, Bali. Jurnal Wacana. 13(1): 93.

Sulistyowati. 2002. Metode Uji Cita Rasa Kopi. Materi Pelatihan Uji Cita Rasa Kopi. Pusat Penelitian Kopi dan Kakao Indonesia. Jember.

Tjiptono, F dan G. Chandra. 2011. Service, Quality and Satisfaction. Andi Publisher. Yogyakarta

Utama, D. 2017. Analisis Sikap dan Kepuasan Konsumen Terhadap Kopi Instan Nescafe dan Torabika Pada Mahasiswa di Universitas Lampung. Skripsi. Tidak dipublikasikan. Fakultas Pertanian. Universitas Lampung.

Walt, R,V. Theuns G.K, and Greyling, M. 2014. Customer Perceptions Of Restaurant Experience In Gauteng. University Of Pretoria. Pretoria, South Africa.

Widiana, K. 2013. Hubungan Karakteristik Sosial Demografis dengan Tingkat Kepuasan dan Loyalitas Pelanggan PT. Asuransi Nusantara Life Cabang BaliNTB di Denpasar. Skripsi. Tidak di publikasikan. Fakultas Ekonomi dan Bisnis. Universitas Udayana. Bali.

Yahya, M. 2009. Pengaruh Kualitas Produk dan Kualitas Pelayanan Barista terhadap Kepuasan Konsumen Kedai Kopi Espresso Bar Solo. Skripsi. Tidak dipublikasikan. Fakultas Keguruan dan Ilmu Pendidikan. Universitas Sebelas Maret. Surakarta. 